\title{
Perspective on Transformative Educational Interventions Developed for Empowerment and Capacitation of Learners in South Africa
}

\author{
Isaiah Mmatipe Sefoka \\ Faculty of Management and Law, \\ University of Limpopo, South Africa \\ Kolawole Sola Odeku \\ Faculty of Management and Law, \\ University of Limpopo, South Africa
}

DOI: https://doi.org/10.36941/jesr-2020-0119

\section{Abstract}

In South Africa, progressive transformative educational interventions have been implemented since the country became a democratic government in 1994. These interventions were meant to eliminate all past colonial and apartheid eras educational segregation laws and policies which denied the black majority access to quality education. This paper explains the intrinsic contents and contexts of these interventions by demonstration how these interventions are being used to redress the past educational segregation and injustices. It highlights that the Constitution provides for the right to education and that other legislation, policies and educational institutions were introduced to enable and ensure the delivery of quality education to learners in order to make them competent and employable in the workplaces and/or to establish their own businesses and be self-employed. The paper concludes that in order to develop capable and competent human capital and resources, access to and delivery of quality education and training are essential potent tools to accomplish this feat.

Keywords: Pedagogy, competency, educators, learners, employability, workplace

\section{Introduction}

In 1994, South Africa became a democratic country, and one of the first steps made to redress the past apartheid injustices was to restructure the legacy of apartheid educational sector in line with the provisions of the Constitution of South Africa, 1996 (the Constitution). (Motala and Pampallis,2019). As such, to realise the fundamental right to education in the post-apartheid era, South Africa reviewed its educational status and introduced a number of policies and legislation on transformation of education to foster flexibility, empowerment, skilled acquisition, capacity development programmes relevant to the $21^{\text {st }}$ century demands (Gamede, 2017). These policies and legislative interventions call for an urgent need for a major investment in education by providing people with quality education and opportunities to become productive in their respective post-education activities (Pegg et al., 2012). In addition, these interventions were aimed at removing the apartheid educational system which discriminated against black South Africans by giving them poor and sub-standard education (Meek 
and Meek, 2008). As such, they were introduced and implemented to transform the educational system by equipping learners with the necessary skills that will make them competent, develop their capacity and to perform optimally in workplaces after graduating (Ming, 2010). Conversely, the apartheid educational system significantly restricted the black majority by training them only to be clerks and interpreters in order to serve the white colonial and apartheid masters.

The Constitution, legislation and government policies on education under the new democratic South Africa have ensured a level playing field for whites and blacks (Clark and Worger, 2016). To this end, these interventions are being strategically implemented to tackle and combat any other form of inequality and unfair discrimination in the educational sector. It is against this backdrop that a variety of government institutions with the support of some private sectors agencies have been established for the purposes of facilitating learning; improving the quality of education and the relationship between education and skills development in South Africa

\section{Research Methodology}

This paper utilized a qualitative research approach by sourcing, utilizing and applying contemporary literature relevant to the issues surrounding access to high-quality education for all citizens regardless of race, religion or creed. Data were collected from numerous secondary bases, predominantly from contemporary literature. Also transformative educational interventions such as government policies, pieces of legislation, case law, scholarly works were relied on and utilized to do a robust analysis on the efficacy and efficiency of the interventions. The work utilized available secondary resources for purposes of gaining insights, reviewing and applying the content to establish that access to quality education is impetus for learners to become competent.

\section{Literature Review}

Education is of utmost importance because it is one of the powerful tools that can be used to sensitise and liberate people from perpetual bondage of fear, ignorance and superstition (Pieterse, 2004). Education is of cardinal importance if acquired as it enables a person to fully participate with understanding and function effectively in a particular society. It is also a basic right on which the realisation of many other rights depend, hence it gives people dignity and self-confidence (Young, 2007). Education is also considered as the cornerstone of any modern democratic society which can be used to give a fair start in life and equal opportunities to citizens of a country. The Committee on Economic, Social and Cultural Rights (CESCR) asserts that access to education must be guaranteed without any discriminatory basis. According to the CESCR, access to education is a human right in itself and at the same time a viable and indispensable means of ensuring that all other human rights are realised. Education is also a powerful tool to be used to empower and capacitate individuals to achieve and realise their dreams. Access to quality education is a panacea for uplifting economically and socially marginalized individuals to escape poverty and become useful member of the community and state (Babaci-Wilhite et al., 2012).

Therefore, the ned to build and foster a system of education and training that reflects the situations in the country and which is embraced and identified by all the people is critically imperative under the current democratic dispensation (Bengu, 1995). In order to achieve this, the system has to be founded on equity and non-discrimination wherein there is broad respect for diversity, honour learning and strive for excellence at all times without leaving anyone behind (Gebremedhin and Joshi. 2016). Communities, role players and stakeholders have to be part and parcel of the system and the system must serve everybody as promoted in the Constitution (Pieterse, 2010). To achieve this, it is strongly argued that all available resources must be used in the most effective and efficient manner possible. It is against this backdrop that the right to education must be prioritised at all cost in all state's budgetary allocation in order to deliver quality education to the people.

It has been observed by Nevondwe and Matotoka (2013), that the right to education as enshrined 
in the Constitution has semblance of a "hybrid right" because it forms part and parcel of socioeconomic rights and such, the government has the obligation to promote, fulfil the right to education to all. Right to education promotes civil and political rights because a well-educated person is empowered and can be able to participate in the on goings in the society and also able to use education and knowledge acquired to fend for self (Nevondwe and Matotoka, 2013).

However, this paper demonstrates that access to education on its own is not enough; it should produce skills and capacity to equip learners in order to perform and or create jobs (NRF, 2012). The paper shows that quality education should be used as a tool to bring profound social change in values and norms and betterment of people's lives. Society cannot be effectively positively transformed without equipping people with quality education (Bentley,2012). Hence, quality education to the people should be utilised as part of transformative tools to impact the society. It further indicates that educational transformation does not merely mean access to education but access to the delivery of quality education to everyone without discrimination (Spreen and Vally, 2006).

Modisaotsile (2012) asserts that quality education ensures sustainable human development, which includes economic and political development systems, which are socially responsible. Every society should use education to build and structure its future. This study indicates that it is through the acquisition of quality education that a society can progressively develop and contribute immensely to the betterment of its people.

Education is one of the powerful tools which is available to every individual to be able to comprehend the meaning of rights, entitlements and broadly to fundamental rights such as the right to freedom of expression, to vote, freedom of information and freedom of association (Tomasevski, 2006). These rights are meaningful exercisable if one is well informed and in the context of a certain minimum level of education having been achieved. As such, these rights are all linked to the right to education. Quality education also empowers an individual to participate meaningfully in the society, make positive contributions toward to self and society (Pavlova, 2008).

The paper highlights that quality education empowers learners and make them to be confident and able to comprehend and promote other human rights and to improve their lives including the lives of others (Tikly and Barrett, 2007). The paper submits that the provision of the right to education must not be subjected to any form of condition or limited and must be made available to every individual unconditionally (McCowan, 2012). This means that quality education must be made sustainably available to everyone regardless of social status (Tikly and Barrett, 2007). It is pertinent to point out that with regard to the right to basic education, which includes adult basic education, this right is not contingent upon and tied to the principle of progressive realisation and the availability of the state's resources. This right has to be provided and fulfilled hence it is a necessity not a privilege. This is the reason while the right is distinguishable from other socio-economic rights.

The most significant requirement for the realization of quality education is to ensure that learners are intensively trained which will result in their receiving a quality education and becoming competitive in all respects. Having an unhindered access to quality education by the learners is an impetus for them to develop themselves to their full potentials in order to become competent and employable (McMahon and Walter, 2009). Therefore, robust training of learners will not only equip them to acquire the required competitive skills that will enable them to fully compete on equal terms with each other for better jobs, but also to create employment and to be self-employed as a measure to defeat poverty and unemployment in South Africa.

An unhindered access to quality education is a formidable tool and formidable that can be used by a disadvantaged and marginalised persons in the society to metamorphosis from abject poverty to a better life and to uplift themselves. Van Leeve (2014) under- resourced poor quality education is antitransformation and undermine the fundamental rights to access to education enshrined in the Constitution. This paper also demonstrates that mere access to education without robust and intensive training to learners do not in any way transform learners to better life and future. Instead, it denies them the opportunity to learn and acquire relevant skills that will make them to be independent, competitive and productive in their workplaces and also to create employment (Boykin and Noguera, 
2011). Therefore, speedy intervention and enforcement of the existing laws and policies promoting the delivery of quality education must be utilised to transform learners to be skilled enough to be employed and create employment (Bailey, 2010).

Government should implement the on the job training programs and implement the laws that promote skills and development such as Skills and Development Act and Further Education and Training Act, which will make learners to acquire relevant skills to do their jobs. The government can achieve this by effectively monitoring and funding the existing skills development and training centres to ensure that learners are taught the necessary skills that will make them employable and selfemployed without any financial difficulty. Sustainable funding as a form of bursaries schemes should be developed, used and extended to the institutions of higher learning such as universities to enable intensive training of students to equip them with relevant and necessary skills to perform productively in their respective chosen fields of study (Helyer and Lee, 2014).

Quality education should be the bedrock of government policy to realize sustainable development in the country by transforming and empowering everyone through skill acquisition (Mapotse, 2020). As such, the government can use the laws to promote delivery of quality education by teaching skills, knowledge and information to learners. This can be done by effectively implementing and enforcing laws, policies and regulations on education and regularly monitoring enforcement progress of such laws for better achievements. It can be done by establishing monitoring and enforcement agencies and or bodies, which will be responsible for the enforcement of laws and directly and regularly report to the government.

This paper submits that it is against this background that quality education must be promoted and be used as a transformative tool to cater for the interests of all, especially the disadvantaged members of the community. In South Africa, legislative and policy interventions have been introduced to accelerate the delivery of quality education, however it is unknown if their objectives are being met. As such, there is a need to scrutinise their effectiveness in order to assess to what extent they have been meeting their objectives.

\section{The Constitution of the Republic of South Africa, 1996}

The Constitution is the supreme law of the country in South Africa. Any obligation imposed by it must be fulfilled, and any law or conduct inconsistent with it are invalid to the extent of their inconsistencies. The Constitution was adopted among others to improve the quality of life of all citizens and to free the potential of every person through the promotion of the rights in the Bill of Rights.

The Constitution provides for the right to elementary education which also includes the right to adult elementary education and access to further education. The state is under constitutional obligation to progressively and sustainably provide and deliver quality education to the people. For purposes of pedagogy, the Constitution allows everyone the right to choose language(s) to be used as medium of instructions in state educational institutions.

Some of these obligations are very distinct and have full backing and support of the Constitution and the court as adumbrated in the case of Governing Body of the Juma Musjid Primary School \& Others $v$ Essay N.O. and Others where the court held that it is salient to understand the nature and meaning of the right to "basic education" under section 29(1) (a) of the Constitution. This is because the right is distinct from other socio-economic rights as contained in the Bill of Rights since it is "immediately realisable." This means that the right does not depend on the availability of state resources for its realisation and it may only be limited in terms of a reasonable and justifiable law of general application. As such, there are policies and legislation that reinforced the right to education as espoused in the Bill of rights in the Constitution and they are discussed below thus:

\subsection{Reconstruction and Development Programme (RDP) 1994}

The Reconstruction and Development Programme (RDP) is a policy adopted in 1994 to ensure that the 
country's human resources are fully developed. This policy is aimed at promoting and developing knowledge and skills of the people through teaching and learning. RDP emphasises that the government has the ultimate responsibility and obligation to ensuring that human resources are fully developed. This paper therefore submit that it is not only the obligation of the state, but also that of individuals like entrepreneurs to provide learning opportunities such as by providing funding to the needy people to acquire knowledge and skills. This means that with the cooperation of various role players and stake holders, there should be collective responsibility for participating in ensuring access to high quality education and the responsibility should not lie exclusively with the government.

Therefore, a variety of community development forums and institutions which include among others; community organisations and private sector agencies have been established for the purposes of facilitating learning; improving the quality of education and the relationship between education and skills development. Some of these community organisations are Joint Education Trust (JET), Youth Development Forum (YDF), National Youth Development Agency (NYDA) and Sector Education and Training Authorities (SETAs). These organisations work hand in hand with the state, the skills development institutions, international development agencies and educational institutions to build quality skills and capacity. This is form of an integrated system of educational training that provides equal opportunities to all irrespective of race, colour or geographical location in South Africa. Essentially, the organisations focus mainly on the development of knowledge, competency and skills that are required in producing quality and standard high-value goods and services to be used in the development of the society.

In addition, the RDP policy provides that creating effective and responsive institutions to manage change in the educational sector is essential for quality education and training. It further provides that "the education and training bureaucracy must be restructured nationally through the establishment of industry-based education and training." The implication of this is that there must be an establishment of learning institution which will develop and promote teaching and learning and as such, provide learners with relevant skills that will enable them to be productive in their respective chosen fields and disciplines. It is for this reason that Tang (2015) stressed that there is a need to focus on restructuring and improving education and training which includes innovative pedagogies. Undoubtedly, by so doing, global relevance of the knowledge, skills, creativity and innovation of the learners in the country will increase. Somavia (2010) indicated that competency and quality skills are the foundation of decent work and as such, it is imperative to utilise education and training as positive responsive methods towards employment challenges. Hence, this study highlights and displays the significance of ensuring that learners of all categories receive high-quality education to enable them create employment, be employable, and to make positive contribution to the economy and society.

\subsection{The White Paper on Education and Training (1995) (WPET)}

The purposes of WPET were to give directions on how the system of quality education should be provided to South Africans. Essentially, the WPET seeks to build an inclusive system of education and training to serve the needs of all interests which is based on equity, non-discrimination and respect for diversity. The system strives for high quality pedagogy and strive for excellence which would deliver quality education and blazes the trail of opportunity and self-fulfilment to the people (Bengu, 1995).

It is pertinent to point out that WPET aims at ensuring that the country's human resources are fully developed through quality education and training which would make the citizens skilled and competent whereby they can be ale to participate actively in all aspects of the economy and development of the society. The implication of this policy is that innovation and training centres providing quality education must be introduced and developed so as to open vast learning opportunities and skills development for every learner. It seeks to achieve human empowerment by introducing quality education and training as a tool to encourage meaningful participation in every process in the society. Salazar (2008) indicates that "quality education, vocational training and lifelong learning are central pillars of employability of workers and sustainable enterprise development within 
the decent work agenda, and thus contribute to achieving the development goals to reduce poverty."

\subsection{South African Qualifications Authority (SAQA), 1995}

This Act was promulgated with the purpose of ensuring quality in education and training. The endorsement of SAQA led to the establishment of a national body called the National Qualifications Framework (NQF). The aim of the "NQF is to create an integrated national framework for learning achievements and facilitating access to mobility and progression within education, training and career paths." As the main objective of SAQA is to "enhance the quality of education and training, there is need to accelerate the redress of past unfair discrimination in education which denied blacks access to quality education. The product of high quality education for all will be better employment opportunities for the previously disadvantaged. Consequently, this will contribute to the personal development as well as the social and economic development of the nation at large. According to Mailaret (1979), receiving quality education enables individual's ability to develop potential talents required to manoeuvre through all the difficulties that weaken the human condition. It is pertinent to also point out that the effective implementation of SAQA will enable the government to ensure that quality training and education of learners would fully equip them to be competitive, employable and create jobs themselves.

The SASA was enacted in 1996 and is aimed at redressing the past injustices based on racial inequality and educational segregation in the provision of education to learners. It is also aimed at providing high quality education that will lay a robust foundation for the development of the learner's skills, talents and capabilities for all learners. As such, the Act seeks to empower schools and communities to make a difference in the societies by establishing frameworks that will make it easy to access quality education.

Parents have obligations to make sure that their children or wards go to school by attending from the first school day of the year in which the learner attains the age of seven years and until the last school day of the year in which the learner attains the age of 15 years or the ninth grade, whichever occurs first.

This means that it is not only the obligation of the state to ensure that every learner receives elementary education. Parents or guardians must partner with the government to ensure that their children go to school. However, in order to ensure quality education in the schools, the State must fund public schools from public revenue and provide every resources that will enable and enhance quality pedagogy in schools. Furthermore, the government should fund skills development institution to provide the learners with the necessary skills. These will make them competent and productive in their respective workplaces and also provide them with the opportunity to create employment for others. Therefore, the government will be contributing to the empowerment of the previously disadvantaged black South Africans by providing everyone with educational competencies which would make them employable, earn incomes, and improve their standard of living and socio-economic status.

\subsection{Higher Education Act (1997) as amended}

The Higher Education Act was promulgated in 1997 in order to provide optimal opportunities for learning and the sustainable creation of knowledge and skills, which include the promotion and full realisation of potential of every student and employee. Section 4 of this Act provides for the establishment of a body known as the Council on Higher Education (CHE), which its main function is to promote quality assurance in higher education as well as promotion of access to higher education institutions including student financial aid. According to Bailey (2014), it is also the aim of the CHE to 
promote quality education and capacity building within the higher education and training institutions.

The Act is also aimed at broadening the learning opportunities and promoting the importance of acquiring the necessary skills. It is for this reason that Medeshova and Amanturlina (2006) indicated that education should improve personal qualities of students and also teach them new practical skills through teaching and learning process. Medeshova and Amanturlina (2006) are of the view that student-centred learning program-which is an approach to learning where learners are given the opportunity to choose not only what to study but also how and why, is as a good method that should be utilised as a learning activity directed at the development of the individual, which provides the skills required to achieve results in pedagogical situations.

\subsection{Skills Development Act (1998) as amended (SDA)}

It is imperative to discuss the concept of skills development before discussing the Act itself. According to Mopeli (2014), the concept of skill development is authoritative within institutions. In organisations, skills development is used as a tool to improve the effectiveness of the organisation 's important resources. Mopeli (2014) argues that skills development is an essential component to ensure that employees perform their work as required and as such, it echoes instructions and/or individual training in the workplace. According to Beardwell and Holden (1997), "skills development supports the approach that South Africa needs to recognize the importance of integrating education, training and skills development as a way of creating an enabling environment for the country to develop workplace competence and stimulate growth for the country." On the other hand, Picard (2005) argues that current problems that the country is encountering are resultant from government's failure to prioritize the implementation of skills development in workplaces. To address these problems, government should intervene by implementing skills development programmes within the South African workforce by promoting self-employment and by increasing the levels of investment in education and training in the labour market. One of the aims of the SDA is to provide employees with the opportunities to acquire relevant skills within their workplace and to encourage the employers to use the workplace as an active learning environment. It is therefore incumbent on the employees to provide opportunities for the workers to acquire new skills that will enhance their incomes and improve the quality of life of workers. The skill should also make workers to be competitive with the possibility of promoting selfemployment.

The SDA is an impetus for the employers to provide ample opportunities for newly qualified entrants to the labour market to work and gain work experience by using the employers' workplaces as an active learning platforms. This study submits that the effective implementation as well as the enforcement of the provisions of the SDA will lead to the realization of the objectives of the Act and the delivery of quality education to South Africans. The study emphasises that the implementation of these provisions will accelerate the paradigm shift towards the delivery of quality education to the people, equip them with relevant skills and training that would enable them to be competitive, employable and create employment. Hence, Greyling (2001) indicates that the SDA is aimed at enhancing the quality of life of all the employees including academics, non-academics and support staff in the higher education institutions. Greyling (2001) posits further that the SDA is aimed at increasing productivity in organisations and institutions and envisaged that by increasing the capacity and competency levels of all employees including educators, this will add real value to the organisational and institutional effectiveness.

\subsection{Further Education and Training Act (1998) (FET)}

The FET commits to provide access to further education and training to previously marginalised communities. It is also aimed at creating an optimal learning and knowledge opportunities, and the creation of a knowledge acquisition. This include the development of intermediate to a high-level skill to these communities in order to enable them to compete with the international standards of academic 
and technical quality. FET establishes a functional national co-ordinated further education and training system which promotes co-operative governance and also provides for programme-based further education and training. This paper accentuates that the purpose of this legislation can be realised by creating programme-based education and training institutions and constantly monitoring those existing in order to deliver quality and relevant skills to the communities involved. Hence, Badat (2010) asserts that "education must cultivate the knowledge, competencies and skills that enable graduates to contribute to the economic development, since such development can facilitate initiatives geared towards creating greater social equality and social development." To achieve this, Badat (2010) indicates that "there is a need for extensive restructuring of all qualifications and programmes in order to ensure that curricula are more congruent with the knowledge, expertise and skills needs of a changing economy." It is therefore reiterated that education should be prioritised by the government, role players and stakeholders. Prioritising education would lead to capacity building, empowerment, skills acquisition and ability to be employable or be self-employed.

\subsection{The Green Paper on Further Education and Training (1998) (GPFET)}

The GPFET facilitates the development of skills to be used for a lifelong learning which would translate to employability and increased productivity in the country. The GPFET implements the implementation of an Outcome-Based Approach to education and training as well as the shift in pedagogy frameworks from content-driven to Programme-Oriented Models. The GPFET linked both theory and practical education and training close together for purposes of receiving training and competency that are more closely to the needs of higher and lifelong learning which would translate to employability and career development. GPFET implements an Outcome- Based Curriculum to which provides many career options for learners. Outcome- Based Curriculum is very relevant to skills acquisition and responsive to the real employment prospects and opportunities that exist beyond schoolings. To achieve this, the GPFET insists on partnerships and collaborations between learning institutions and employers to establish training centres in order to expand the range of learning and training opportunities.

In South Africa, colleges and FETs are centres of knowledge and skills acquisitions expected to contribute immensely to develop, expand and equip learners with relevant skills to enable them to be employable and to create jobs for others. Yet, they offer education which are inferior and poor and of low standard as a result of the lack of sustainable funding (Sheppard and Lydia Ntenga, 2014). This lack has led to employment of inadequately qualified educators; insufficient industry-linked programmes and a limited programme qualification which lack programmes relevant to the local communities and industry it serves (Sheppard and Ntenga, 2014).

Therefore, implementation strategies and useful lessons, such as sustainable funding of skills development institutions and effective educators' training, must be prioritised by the government in order to achieve the desired outcomes of building capacity and competency. By so doing, there will be positive impact on the social and economic development of the community (Seng, 2007).

\subsection{Education White Paper 4 (1998) (EWP4)}

In 1998, the Department of Education introduced an EWP4, which commits to the establishment of FET system which is responsive to the needs of the people and that will immensely contribute to developing skilled and competent learnerst (Bengu,1998). There are quite an adequate number of FETs in South Africa offering diverse programs. However, the delivery of quality education at FETs is still poor as graduates from these FETs are often described as being incompetent by their employers (CED, 2015). As such, they often perform their duties under a maximum supervision, which shows that they are not properly trained and lack the required skills. The foundation of the problem is that incompetent educators were mostly hired to deliver pedagogy, hence the production of incompetent graduates. Hofmeyr and Draper (2015) assert that "a qualified educator is not necessarily a good educator and not 
all qualified educators are competent professionals able to provide quality teaching and learning." Hofmeyr and Draper (2015) further assert that "it is common cause that the quality of most educational institution programmes leaves a lot to be desired and the result is that most of the current teaching force has been inadequately educated and trained to impart the necessary skills and knowledge to the learners." They concluded by asserting that "improving the capacities of educators is urgent and essential. Otherwise expanding access without actual delivery and provision of quality education will only reproduce more poor quality educators with inadequate subject and pedagogical knowledge and limited teaching skills, which leaves them ill-prepared for the challenges of classroom teaching and pedagogical innovations."

This paper submits that access to education on its own is not enough, it must be coupled with intensive physical and actual delivery which will enable the learners to be competent and able to function and perform independently with minimum or without supervision. The paper further submits that capacitation of educators is the most cardinal point in the educational sector for the realisation of quality education. Hence, Adedeji and Olaniyan (2012) assert that "capacitated educators are the important instruments which a country can utilise for the sustainable development and improvement of its educational system." Adedeji and Olaniyan (2011) point out that "any socio-economic strategy, aimed at improving schools and human development must, consider continuous teacher development programs and for a country to improve its educational system it needs to provide workable strategies that will improve the capacity and conditions of educators and teaching in schools."

\subsection{Adult Basic Education and Training Act (2000) (ABET)}

In 2000, ABET was established to provide adults who were still willing to be educated the opportunity to attend school. However, for this Act to work effectively, it requires governance and funding of public adult learning centres. Competent and qualified educators are also essential in order to ensure quality pedagogy. McKay (2007) observed that ABET has to provide adult learners who would like to participate in ABET programs, with the foundation for lifelong learning and equip them with required skills and critical capacity to participate fully in society. According to McKay (2007) ABET refers to education which provides individuals the opportunity to "improve their life chances and it also refers to the foundational income-generating or occupational skills that individuals require to improve their livelihoods and living conditions. The ABET provides adults with the foundational knowledge, skills, understanding and abilities that are required to improve their social and economic life.” McKay (2007) asserts that training of adults would make them to be competent having taken part and acquired understanding, skills, knowledge and abilities to be employable and create employment. The ABET also provides the opportunity for adults to further their studies if they have the aspiration to do so.

According to the Department of Education Policy document on Adult Basic Education and Training of 1997, "ABET provides the foundation of fundamental skills, knowledge, and understanding that gives people a basis from which they can progress along a chosen career and life path." This paper submits that in order for South Africa to have quality adult education, these type of education must be must be promoted and strongly monitored on regular basis according to the provisions of ABET and other relevant legislation promoting access to quality adult basic education and training.

\subsection{The National Plan of Action (NPA) 2003}

The NPA seeks to "improve access to free and quality basic education for all." The plan provides that "it is well on the way to attaining the provision of basic education that is compulsory for all children of school-going age, that is of good quality and in which financial capacity is not a barrier for any child before 2015." To this end quality education should be made free for all. This entails there must be available funds to cater for the educational requirements need of a learner and should be adequate to cover all the costs for access to quality education; by attending school, this should equip all the learners with the required knowledge and skills that will enable them to participate fully in the country's 
economic, political and cultural life; and also all barriers that would inhibit the attendance of learner at the elementary level should be dismantled and removed.

This notwithstanding, it is pertinent at this juncture to point out that the quality of education is being compromised as learners attend schools, but they are receiving poor education due to lack of qualified and competent educators and poor educational infrastructure (Hofmeyr and Draper, 2015). To attain the delivery of quality education, there must be holistic interventions and funding for education in order to develop and train competent learners.

\subsection{Broad-Based Black Economic Empowerment Act (2003) as amended (BBBEE)}

This BBBEE was enacted in 2003 to ensure equitable training that is free from racial discrimination, to ensure meaningful participation of blacks in the economy and to increase their employment opportunities. The BBBEE is a process of economic empowerment by the government in an attempt to provide the black people with economic power. Hence, Mparadzi and Kalula (2007) posits that the BBBEE was introduced to balance the economic empowerment between black and white communities in South Africa. Its goal is to distribute the country's wealth across all the South Africans, particularly the historically disadvantaged South Africans. On the other hand, Osode (2004) avers that the BBBEE is a process aimed at spreading equity holdings by incorporating the previously disadvantaged society, re-organising management structures and ensuring their participation in the economy to achieve economic justice. The main objective of the BBBEE is to promote economic transformation by enabling effective participation of blacks and to empower them by increasing their access to economic activities and skills training. It is also aimed at redressing the imbalances caused by apartheid by empowering rural communities to access relevant skills and to promote access to finance for black economic empowerment. In addition, the BBBEE formed a body known as the Black Economic Empowerment Advisory Council (BEEAC), with the main function to advise the government on black economic empowerment as well as to monitor progress in achieving black economic empowerment.

This paper submits that education as a viable tool to mainstream the previously denied black South Africa to acquire skills. Capacity and competency which would create unhindered opportunity for them to be able to participate meaningfully in the economic development of South Africa. In affirming the significance of access to quality education, Thomas and Salisu (2014) posits that "quality education has for long been recognized as a basic tool for economic development of any nation and it empowers any nation to rise to the challenges of social and economic transformation as well as technological change."

Therefore, there is need to make massive investment in quality education. Thomas and Salisu (2014) also assert that the "rationale for investing in education is based on the expectation of its role in contributing to social reconstruction and economic development as well as creation of sustainable economic growth." Hence, in order to transforming the economy for sustainable development, there is need to massively invest in quality education because it has a link with nation building and economic development. In the same manner Alufohai (2012) indicates that "educational institutions are centres for educating, creating information and imparting knowledge, which is of utmost importance to the people for the development and management of the future for sustainability in different societies." Otoh (2012) avers that quality education is of great importance in socio-economic development and a vital process in economic growth hence it contributes to the construction and advancement of knowledge to sustain the nation. This paper submits that for South Africa to escape the threats to its economic development and stability, it should invest more in quality education.

\subsection{Continuing Education and Training Act (2006) as amended (CETA)}

The CETA as amended was enacted in 2006 and it established a Community Education and Training Colleges (CETCs) within the Post-School Education and Training system. It aimed at ensuring ample access to basic adult education, further education and training to previously marginalised people 
through continuing education and training, even to the workplace. It created optimal learning opportunities and robust knowledge acquisition, the development of intermediate to high-level skills to previously marginalised people in order to enable them to compete based on international standards of academic and technical quality. Section 2 of CETA provides that "the purpose of this Act is to enable students to acquire the necessary knowledge, relevant practical skills and applied vocational and occupational competence and also to provide students with the necessary attributes required for employment, entry to a particular vocation, occupation or trade."

\subsection{Green Paper for Post-School Education and Training (2012) (GPPSET)}

The GPPSET aimed at improving educational system of South Africa where learners, particularly those in work places, are qualified and receive competency that will expand job opportunities for them, become employable and build sustainable livelihoods. The GPPSET presents an overview of how the educational system must be structured, improved and developed in a democratic dispensation to upgrade the lives of the people (Gounden, 2012).

It is pertinent to point out that due to apartheid segregation policy and law which denied them requisite funding to be at par with their white counterparts, virtually all education institutions in the historically black areas in South Africa are still under-resourced and disadvantaged till date. As such, there are insufficient PhDs from black South Africans, especially those who are women. To address this, the Department of Science and Technology in South Africa (DST) targeted "a five-fold increase in $\mathrm{PhDs}$ over the next 10 years in order to increase the numbers of PhDs in South Africa." The reason for this is to bridge the knowledge gap by redressing past educational injustices. Hence, the need to empower and building capacity amongst the historically disadvantaged group by providing them access to education, which would enable them to acquire required skills and become competent. To this end, the paper provides that "the production of PhDs among black students and female students provides the solution to both improving the demographic profile of academic staff at the historically white institutions and providing the human resources needed to improve the quality of the historically Black institutions."

The paper envisaged that by 2030 the country should have a post-secondary school system that will change the face of education and training in the post-school sector as follows:

- "Providing a range or multiple of accessible alternatives and choices for young people.

- Raise the universities' enrolments to 1500 ooo (projected at 23\%) as opposed to 2011 enrolment figure of 899120.

- 4000 enrolments (about a $60 \%$ participation rate) in colleges or other post-school institutions, with a key focus on Further Education and Training (FET) colleges.

- Improving the quality of the FET colleges, developing innovative programmes and upgrading lecturer qualifications.

- Addressing insufficient levels of research and innovation echoing the DST Ten-Year Innovation Plan.

- Establishing an institution that will cater for the needs of out of school community.

- Establishing a South African Institute for Vocational and Continuing Education and Training (SAIVCET) as part of a long-term strategy to build institutional capacity.

- Addressing the link between the secondary, post-secondary and labour market.

- Establish institutions that will provide a link between education, training and labour market.”

It is pertinent to point out that it is not the number of students that enrol that is really significant, but the quality of training and education received during the course of studies. Similarly, provision and delivery of quality education to the learners are driven by well qualified and competent educators. Therefore, educators too should be constantly exposed to more training and workshops that would make them contemporary in discharging pedagogy. Hence, Adedeji and Olaniyan (2011) opined that the improvement of educational institutions and the development of human capacity to flourish in a 
country, continuous educators' development programs must be considered and for that country to have the best quality education, it must provide sustainable pedagogical innovative strategies that will improve the capacity and conditions of educators and teaching in schools.

\subsection{The White Paper for Post School Education and Training (WPPSET) 2014}

The WPPSET seeks sets out relevant strategies to expand the provision of quality education and training in South Africa, to improve its quality, and to set out strategies and ways in which employers in both private and public sectors can play a significant role in the creation of a highly skilled labour force. The WPPSET is aimed at outlining a framework that defines the Department's focus and priorities in creating robust development plan for a period up to 2030. The Paper's main objectives are among others to establish and develop:

- "A post-school system that can assist in building a fair, equitable, non-racial, non-sexist and democratic South Africa;

- A single, coordinated post-school education and training system;

- Expanded access, improved quality and increased diversity of provision of quality education;

- A robust interaction between education and training institutions such as FETs and colleges and the workplace;

- Education and training system that is responsive to the needs of learners and undergraduates, employees in both public and private sectors, as well as the society at large."

These objectives are of paramount importance in the development of the South African educational system, however, they have not been implemented yet, and as such it adversely contributes to the poor educational system. Whereas, if implemented it will positively contribute to the upbringing and provision of good quality education. The WPPSET provides that "the education and training system must find ways to cater for the needs of the millions of adults and youth who are unemployed, poorly educated and not schooling."

It is based on these plans that the paper accentuates that there must be access and provision of quality education which makes quality an integral part of access in order to realise the delivery of quality and high standard education. In 2015, Nzimande commented on the preamble of this policy that:

"this White Paper is a vehicle which would drive and deepen transformation of the entire post-schooling sector. It will provide a framework to build on the achievements of our democratic government since 1994. It is on the foundations of these achievements that we intend to tackle many challenges that still lie ahead. The White Paper will empower us as we strive to build a post-school education and training system that is able to contribute to eradicating the legacy of apartheid. It will assist us to build a prosperous South Africa characterised by progressive narrowing of the gap between the rich and the poor. Access to quality post-school education is a major driver in fighting poverty and inequality in any society."

Nzimande (2015) stressed further that "the education and training system should not only provide knowledge and skills required by the economy. It should also contribute to developing thinking citizens, who can function effectively, creatively and ethically as part of a democratic society. They should have an understanding of their society, and be able to participate fully in its political, social and cultural life."

According to Manana (2015), the WPPSET is the cornerstone for the transformation of the educational system in South Africa. Manana (2015) indicates that "this policy is consistent with the National Development Plan in that its mandate is to create a range of highly qualified and skilled society that can play a crucial role of growing the emerging sector of our economy thereby creating massive employment opportunities for youth."

The authors submit that the objectives of this policy are useful and need to be implemented in order to be realised. If these objectives are implemented the learners will acquire high level of skills, 
knowledge and capacity, be employable and be able to create employment for others thereby contributing to the economic growth. These assertions are supported by Zimbo (2013) thus "education is an essential ingredient for socio-economic development; hence educated individuals possess the ability and high chance to secure both the basic necessities for survival and the other material goods required for flourishing such as a good and sustainable employment which improves personal income and the ability to escape poverty."

\subsection{A Work Place-Based Learning Policy (2015) (WPBL)}

The WPBL commits at creating radical transition from learning to work in order to enhance employability. The workplace-based learning is as "an educational approach through which a person internalises knowledge, gains insights and acquires skills and competencies through exposure to a work-place to achieve specific outcomes applicable to employment." This WPBL provides that "Work Place-Based Learning must be provided to students to enable them to acquire skills and to be employable."

This authors submit that learners must be trained and acquire relevant quality skills prior to their entry into their respective workplaces. The working class must not be exempted. They should also be trained with the relevant skills in order to be productive in their chosen work fields. These assertions are substantiated by the 2008 International Labour Conference report, which provides that "skills development is central to improving productivity. In turn, "productivity is an important source of improved living standards and growth which include critical factors such as employment growth, sustainable enterprise development and fundamental investments in quality education and training." Therefore "effective skills development systems which connect education to technical training, technical training to labour market entry and labour market entry to workplace and lifelong learning can help a country to sustain productivity growth and translate that growth into more and better quality jobs."

On the other hand, Quintini and Pouliakas (2014) indicate that "bringing education and the working world closer together is necessary for successful and coordinated strategy that build solid skills through high quality education, while involving all relevant stakeholders in the skills development process throughout an individual's life is required." Quintini and Pouliakas (2014) further assert that other than learning on the job, work-based and job specific skills must be acquired at schools.

\subsection{National Policy on Community Education and Training Colleges (2015) (NPCETC)}

The NPCETC serves as an initial process in establishing an overarching institutional policy framework for the establishment of Community Education and Training Centre (CETCs). It provides that "access to education and training must be made available through viable institutions to the employed and unemployed, young and old to encourage an economically active population and community participation."

It seeks to achieve the establishment of innovation and training centres amongst the communities, which will transform and capacitate everyone including employed, unemployed, young and old in order to encourage their positive participation towards the economy. The intensive participation of the community in the innovation and training centres will ensure that the members of the community receive quality education which will enable them to secure and create valuable jobs and opportunities.

\section{Synthesis}

The paper explains various transformative interventions that have been strategically introduced to provide and deliver high quality education in order to make learners competent. However, incompetent educators and lack of proper infrastructure are impediments to the realization of the right 
to access to high quality pedagogy and education. In the same vein, poor educational infrastructural amenities and services are also contributing to the poor delivery of quality education because learners would not be able to perform optimally under environments and conditions that are not conducive for teaching and learning. Therefore, there is a need for government to ensure that well qualifiedcompetent educators and adequate educational infrastructural amenities and services are made available to learners to enable them to learn under conducive learning environments with adequate resources necessary to provide and deliver quality education. The government must also ensure that there is ample funding for educators' capacity building programmes. In order to improve and strengthen implementation of these interventions, government needs to invest more in education postapartheid. Against the backdrop of this, by receiving high-quality education, this has the potential to make learners competent and become employable, create jobs and be self-employed; and even become employers.

\section{Conclusion}

It is clear that there are ample transformative educational interventions that have been introduced and being implemented to provide quality education to all in South Africans. These interventions are imperative because they are also the impetus for ensuring the delivery of high standard pedagogy to learners. To facilitate the delivery of high quality education to the learners, educators play critical roles, as such, competent and qualified educators should be hired to provide and deliver pedagogy to learners.

\section{References}

Adedeji, S.O. \& Olaniyan, O. (2011). Fundamentals of teacher education development; improving the conditions of teachers and teaching in rural schools across African countries, United Nations Educational, Scientific and Cultural Organization (UNESCO), International Institute for Capacity Building in Africa (IICBA) Addis Ababa.

Alufohai, E. (2012). Enhancing teaching and learning for sustainable development in Nigeria Higher Institutions of Learning. Journal of Educational Review, 5(2):137-142.

Babaci-Wilhite, Z.; Geo-JaJa, MA \& Lou. S. (2012). Education and language: A human right for sustainable development in Africa. International Review of Education, 58:9-64.

Badat, S. (2010). The challenges of transformation in higher education and training institutions in South Africa, Development Bank of Southern Africa. Retrieved from: https://www.dbsa.org/EN/AboutUs/Publications /Documents/Toby\%2oSaleem\%2oBadat.pdf.

Bailey, T.R. (2010). Learning to work: Employer involvement in school-to-work transition programs. The Booking Institution Publication.

Bailey, T. (2014). The Role and functions of Higher Education Councils and Commissions in Africa, A case study of the Mozambique National Council on Quality Assurance in Higher Education. Compress Dsl Centre for Higher Education Transformation (CHET).

Beardwell, I. \& Holden, L. (1997). "Human Resource Management: A Contemporary Perspective", Pitman Publishing, London.

Bentley, T. (2012). Learning beyond the classroom: Education for a changing world. Digital Printing, USA.

Bengu, S. (1998). Commending on the Education White Paper 4- A Programme for the Transformation of Further Education and Training, 1998. Retrieved from: https://www.education.gov.za/Portals/o/Documents /Legislation/White\%2opaper/White\%2opaper\%2oon\%2oEducation\%2oand\%2oTraining\%201995.pdf?ver=2 oo8-03-05-111656-0oo.

Boykin, A.W. Noguera, P. (2011). Creating the opportunity to learn: Moving from research to practice to close the achievement gap. ACSD Publications.

CED, 2015. Centre for Enterprise Development, a Johannesburg-based research institute, 2015 page 23. Retrieved from: www.cde.org.za

Clark, N.L. \& Worger, W.H. (2016). South Africa: The rise and fall of apartheid 2016 3rd Edition Routledge, Taylor and Francis Group, New York, NY. 
Gamede, N.W. (2017. Human capital development in South Africa: perspectives on education in the post-apartheid era Master of Commerce. University of South Africa. Retrieved from: https://core.ac.uk/download/pdf/132283618.pdf.

Gebremedhin, A. \& Joshi, D. 2016. Social justice and human rights in education policy discourse: Assessing Nelson Mandela's legacy. Education as Change, 20(1): 72-198.

Greyling, L. (2001). Skills development: a strategic perspective. South African Journal of Higher Education, 15(2): 3740.

Helyer, R. \& Lee, D. (2014). The role of work experience in the future employability of higher education graduates. Higher Education Quarterly, 68(3):348-372.

Hofmeyr, J. \& Draper, K. (2015). Teachers in South Africa, supply and demand 2013-2025, the executive summary, The Centre for Development and Enterprise (CDE) 2015. Retrieved from: website www.cde.org.za.

Mapotse, T.R. (2020). Technical Education Through Action Learning: Bedrock of Sustainable Development. Retrieved from: https://link.springer.com/referenceworkentry/10.1007\%2F978-3-319-95870-5_48.

McCowan, T. (2012). Human rights within education: Assessing the justifications. Cambridge Journal of Education, $42(1): 67-81$.

McKay, V. 2007). Adult Basic Education and Training in South Africa, National Center for the Study of Adult Learning and Literacy (NCSALL). Retrieved from:www.ncsall.net/fileadmin/resources/ann_rev/rall_v7_ch9.pdf.

McMahon, WW. Walter, W. (2009). Higher learning, greater good: The private and social benefits of higher education. John Hopkins University Press.

Medeshova,A.; Amanturlina, G; \& Sumyanova, E. (2016), Development of Training Skills in Students as the Precondition for Educational Competencies, International Journal Of Environmental E Science Education. 11(17):9649-9656.

Meek, C, \& Meek, J. (20o8). The History and Devolution of Education in South Africa. In: Holsinger D.B., Jacob W.J. (eds) Inequality in Education. CERC Studies in Comparative Education, vol 24. Springer, Dordrecht.

Mialaret, G. (1979). The child's right to education, United Nations Educational, Scientific and Cultural Organization (UNESCO).

Ming,T., Hall, C., Azman., H., \& Gordon J. (2010). Supporting Smart School Teachers' Continuing Professional Development in and through ICT: A model for change. International Journal of Education and Development using ICT, 6(2): 5-20.

Modisaotsile, B,M. (2012). The failing standard of basic education in South Africa. Policy brief, 72:1-8.

Mopeli, S.A. (2014). Training and skills development of senior municipal officials in the Johannesburg Metropolitan. Retrieved

from: https://www.researchgate.net/publication/309752984_implementation_of_skill_development_act_in_the_S outh_African_construction_industry/citation/download.

Motala. E. \& Pampallis, J (2019). The state, education and equity in post-Apartheid South Africa: the impact of state policies. Routledge Publishers.

Mparadzi, A. \& Kalula, E. (2007). Black economic empowerment in South Africa: A critical appraisal”, Institute of Development and Labour Law, University of Cape Town, Monograph No. 1: 7-20.

NRF, (2012). National Research Council. Education for life and work: Developing transferable knowledge and skills in the 21st century. The National Academies Press, Washington, USA.

Osode, P.C. (2004). The New Broad-Based Economic Empowerment Act: A Critical Evaluation. Speculum Juris, 18(1):114-121.

Otoh, T.N. (2012). Revitalizing higher education for socio-economic development. Nigerian Higher Education Journal, 263-272.

Pavlova, M. (2008). Technology and vocational education for sustainable development: Empowering individuals for the future. Springer Publication.

Pegg, A.; Waldock, J.; Hendy-Isaac, S.; \& Lawton, R. (2012). Pedagogy for Employability. York, UK: Higher Education. Retrieved from: http://oro.open.ac.uk/30792/.

Picard, L.A. (2005). The State of the State: Institutional Transformation, Capacity and Political change in South Africa. Paarl Print, Johannesburg, South Africa.

Pieterse A. (2004). The transformative nature of the right to education. Tydskrif vir die Suid-Afrikaanse, 4(1): 70o714 .

Pieterse, G. (2010). Establishing a framework for an integrated, holistic, community based educational support structure. Retrieved from: https://pdfs.semanticscholar.org/eifc/d84aee7fc7deo14ecdddafd1305c8ceff248.pdf.

Quintini, G. \& Pouliakas, K. (2014). Matching Skills and Labour Market Needs Building Social Partnerships for Better Skills and Better Jobs, World Economic Forum Global Agenda Council on Employment, Davos-Klosters, Switzerland. 
Salazar, J.M. (2008). Conclusions on skills for improved productivity, employment growth and development, International Labour Conference held at the International Labour Office Geneva.

Sheppard, C. \& Ntenga, L. (2014). Funding of the South African Further Education and Training sector for an equitable sharing of national revenue. https://www.google.co.za/search?q=Sheppard+and+Ntenga+2014\&oq=Sheppard+and+Ntenga+2014 \&aqs

Somavia, J. (2010). A Skilled Workforce for Strong, Sustainable and Balanced Growth: A G2o Training Strategy, International Labour Office - Geneva, ILO Publications.

Spreen, C.A. \& Vally, S. (2006). Education rights, education policies and inequality in South Africa International Journal of Educational Development, 26(4):352-362.

Tang, K.N. (2015). Critical Issues of Soft Skills Development in Teaching Professional Training: Educators' Perspectives, 6th World conference on Psychology Counseling and Guidance, 14 - 16 May 2015, Elsevier Ltd.

Thomas, O.A.; Salisu, R.A.; \& Thomas, S.A. (2014). The Role of Higher Education in Economic Transformation and Sustainable Development in Nigeria. The European Conference on Education, Official Conference Proceedings.

Tikly, L. \& Barrett, A.M. (2007). Education quality: Research priorities and approaches in the global era. Retrieved from: http://citeseerx.ist.psu.edu/viewdoc/download?doi=10.1.1.470.9537\&rep=rep1\&type=pdf.

Tomaševski, K. (2006). .The State of the Right to Education Worldwide: Free or Fee? Retrieved from: https://brill.com/view/book/edcoll/9789087904920/BPooooo3.xml.

Van Leeve, Y. (2014). Mobilising the right to a basic education in South Africa: What has the law achieved so far? The Department of Education Publication.

Young, M. (2007). Bringing knowledge back in: From social constructivism to social realism in the sociology of education. Routledge Taylor and Francis.

Zimbo, C. (2013). The right to basic education, the South Africa constitution and the Juma Masjid case: an unqualified human right and a minimum core standard. Retrieve from: http://dx.doi.org/10.4314/ldd.v17i1.23> d 29-09-2018. 